\title{
Recommendation of Yogyakarta tourism based on simple additive weighting under fuzziness
}

\author{
Eko Yunanto Utomo \\ Postgraduate Student of Mathematics Department, Faculty of Science and Mathematics, \\ Universitas Diponegoro, Indonesia
}

\begin{tabular}{l} 
Article Info \\
\hline Article history: \\
Received Jan 14, 2021 \\
Revised Feb 20, 2021 \\
Accepted March 12, 2021 \\
\hline
\end{tabular}

\section{Keywords:}

Tourism

Triangular fuzzy number Multi-attribute decision making Simple additive weighting

\begin{abstract}
Tourists who do not understand the situation or the desired tourist attraction can choose tour and travel services. Tour and travel provide a choice of tour packages with various variations. Determining the right tour and travel package and agency can benefit tourists, both in terms of financial and vacation quality. The data used in this study were obtained from several Tour and Travel agents. There are several variables used, namely the price of the package, the number of participants, and the number of facilities obtained. The method used in this study combines the Triangular Fuzzy Number (TFN) and the Simple Additive Weighting (SAW) method. The purpose of this study is to help tourists determine the most profitable or best packages. The results of this study obtained the best 2 packages recommended for tourists to choose. In the SAW calculation, it can be seen that packages that have a preference value above 0.7 are highly recommended to be selected. Meanwhile, preference values above 0.6 to 0.7 are still considered to be selected, because they have an advantage in one of the criteria. For preference values below 0.6 , it is not recommended to choose because the package is too expensive and not worth what you get.
\end{abstract}

This is an open-access article under the CC BY-SA license.

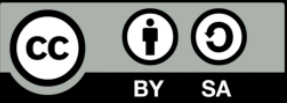

\section{Corresponding Author:}

Eko Yunanto Utomo,

Postgraduate Student of Mathematics Department,

Faculty of Science and Mathematics, Universitas Diponegoro,

J1. Prof. Sudarto No.13, Tembalang, Semarang, 50275, Indonesia.

Email: ekoyunanto1358@gmail.com

\section{INTRODUCTION}

Tourism is an important economic sector to support the progress of a country [1]. Both local and foreign tourists are business opportunities for several companies engaged in the tourism sector. So that a tour and travel agency emerged whose function was to assist tourists in accommodation, transportation, and famous tourist objects in certain areas [1]-[3]. It also [4] helps tourists identify popular tourist objects, especially in the Province of Yogyakarta Special Region.

The method used is Simple Additive Weighting (SAW) with fuzzy additions to help solve uncertain problems. The basic concept of the SAW method is to find the weighted sum of the performance ratings for each alternative in all attributes [5]-[7]. The advantage of the SAW method is to make a more precise assessment because it is based on predetermined criteria and weight values [8]-[11].

In [12], [13] use AHP and SAW methods. In [14]-[17], use the TOPSIS and SAW methods. In [18], [19] uses the SAW method to build a decision support system for selecting Banjar restaurants in Banjarmasin city. Based on several previous studies, it can be seen that the SAW method can be used to assist in decisionmaking. So that the Fuzzy SAW method can also be used to help make decisions on Tour and Travel problems. 


\section{METHOD}

The method used to solve the problem of determining tourism is SAW using the TFN. The selected input variables are price, the number of participants, and the number of facilities available. The data is obtained from several tour and travel websites in Yogyakarta Special Region Province.

\subsection{Triangular Fuzzy Number (TFN)}

TFN denotes the relative strength of each feature pair in the same hierarchy and can be indicated as $M=(l, m, u)$, where $l \leq m \leq u$. The membership function of the TFN can be defined as follows.

$$
\mu_{M}(x)= \begin{cases}0 . x<\text { latau } x>u \\ \frac{x-l}{m-l}, & l \leq x \leq m \\ \frac{u-x}{u-m}, & m \leq x \leq u\end{cases}
$$

\subsection{Fuzzy Simple Additive Weighting (FSAW)}

FSAW is a method that is often used to solve problems in spatial decision analysis [20], [21]. This method requires the process of normalizing the decision matrix $(\mathrm{X})$ to a scale that can be compared with all existing alternative ratings [22]. The Fuzzy SAW method is divided into 2 criteria, namely benefit (profitable) and cost (disadvantage) [23]. The steps of the Fuzzy SAW method are as follows.

First, changing all alternatives into a TFN form or called fuzzification. Second, classifying the benefit and cost criteria to determine the normalization formula. Third, normalize using the following formula.

$$
r_{i j}=\left\{\begin{array}{l}
\frac{X_{i j}}{\max X_{i j}}, \text { if } j \text { is benefit criteria } \\
\frac{\min X_{i j}}{X_{i j}}, \text { if } j \text { is cost criteria }
\end{array}\right.
$$

where $r_{i j}$ is the normalized performance rating of the alternatives $A_{i}$ on criteria $C_{j}$ with $i=1,2, \ldots, m$ and $j=$ $1,2, \ldots, n$. Preference value for each alternative $\left(V_{i}\right)$ as follows.

$$
V_{i}=\sum_{j=1}^{n} w_{j} r_{i j}
$$

where $V_{i}$ is the preference value and $w_{j}$ is the ranking weight.The value of $V_{i}$ the larger one indicates that the alternative is preferred.

\section{RESULT AND DISCUSSION}

In making decisions about determining tour and travel, researchers use 3 criteria, namely price, number of participants (NoP), and number of facilities. In Table 1, we can see the data that will be used in this study. The tour and travel data below is obtained from several tours and travel agencies and the data below has been grouped according to the existing variables

The step that needs to be done is to change the crisp numbers into fuzzy numbers (fuzzification), with the following groupings Low $(1,1,3)$, Medium $(1,3,5)$, and High $(3,5,5)$. Fuzzification results can be seen in Table 2.

The next step is to determine the benefit and cost criteria for this research. The criteria included in the benefits are the number of participants and the number of facilities, while the cost criteria are the package price. Furthermore, normalization is carried out for each alternative, according to the formula for the benefit and cost criteria. After getting a normalized performance rating, we continue to look for the preferential value. The prevalence value is obtained by multiplying the normalized performance rating of each alternative with each criterion weight. The weights for each criterion are as follows, Price $(0.2072 ; 0.4145 ; 0.5181)$, number of participants $(0.1036 ; 0.2072 ; 0.4145)$, and number of facilities $(0.2072 ; 0.4145 ; 0.5181)$. The preference value of each alternative can be seen in Table 3 . 
Table 1. Data on tour and travel vacation packages.

\begin{tabular}{ccccc}
\hline No. & Package Name & Price & NoP & Facilities \\
\hline 1. & Gua Pindul1 & 290.000 & 4 & 7 \\
2. & Kalibiru1 & 220.000 & 4 & 7 \\
3. & Merapi Lava Tour & 310.000 & 4 & 7 \\
4. & Rafting Sungai Elo & 390.000 & 5 & 6 \\
5. & Snorkeling & 240.000 & 4 & 7 \\
6. & Sunrise & 220.000 & 6 \\
7. & Mangunan & 310.000 & 8 \\
8. & Gua Pindul2 & 320.000 & 8 \\
9. & Merapi & 350.000 & 8 \\
10. & Kalibiru2 & 320.000 & 3 & 7 \\
11. & Indrayanti & 300.000 & 4 & 6 \\
12. & Candi Borobudur & 270.000 & 3 & 6 \\
13. & Gua Pindul3 & 290.000 & 4 & 6 \\
14. & Hutan Pinus & 240.000 & 3 & 6 \\
15. & Kalibiru3 & 360.000 & 4 & 7 \\
16. & Air Terjun Sri Gethuk & 220.000 & 3 & 6 \\
17. & Umbul Ponggok & 320.000 & 5 & 6 \\
18. & Candi Prambanan & 230.000 & 4 & 6 \\
19. & Indrayanti & 270.000 & 4 & 6 \\
20. & Rafting Sungai Elo & 425.000 & 3 & 5 \\
21. & Keraton Jogja & 225.000 & 5 & \\
22. & Dieng Wonosobo & 350.000 & 3 & \\
23 & Keraton Solo & 215.000 & 3 & \\
\hline
\end{tabular}

Table 2. Triangular Fuzzy Number from Data

\begin{tabular}{ccccc}
\hline No. & Package Name & Price & NoP & Facilities \\
\hline 1. & Gua Pindul1 & $(3,5,5)$ & $(1,3,5)$ & $(3,5,5)$ \\
2. & Kalibiru1 & $(1,3,5)$ & $(1,3,5)$ & $(3,5,5)$ \\
3. & Merapi Lava Tour & $(3,5,5)$ & $(1,3,5)$ & $(3,5,5)$ \\
4. & Rafting Sungai Elo & $(3,5,5)$ & $(3,5,5)$ & $(1,3,5)$ \\
5. & Snorkeling & $(1,3,5)$ & $(1,3,5)$ & $(1,3,5)$ \\
6. & Sunrise & $(1,3,5)$ & $(1,1,3)$ & $(3,5,5)$ \\
7. & Mangunan & $(3,5,5)$ & $(1,3,5)$ & $(1,3,5)$ \\
8. & Gua Pindul2 & $(3,5,5)$ & $(1,1,3)$ & $(3,5,5)$ \\
9. & Merapi & $(3,5,5)$ & $(1,3,5)$ & $(3,5,5)$ \\
10. & Kalibiru2 & $(3,5,5)$ & $(1,1,3)$ & $(1,5,5)$ \\
11. & Indrayanti & $(3,5,5)$ & $(1,1,3)$ & $(1,3,5)$ \\
12. & Candi Borobudur & $(1,3,5)$ & $(1,1,3)$ & $(1,3,5)$ \\
13. & Gua Pindul3 & $(3,5,5)$ & $(1,3,5)$ & $(1,3,5)$ \\
14. & Hutan Pinus & $(1,3,5)$ & $(3,5,5)$ & $(3,5,5)$ \\
15. & Kalibiru3 & $(3,5,5)$ & $(1,3,5)$ & $(1,3,5)$ \\
16. & $(1,3,5)$ & $(1,3,5)$ & $(1,3,5)$ \\
17. & $(3,5,5)$ & $(1,1,3)$ & $(1,3,5)$ \\
18. & Tir Terjun Sri Gethuk & $(1,3,5)$ & $(3,5,5)$ & $(1,3,5)$ \\
19. & Umbul Ponggok & $(1,3,5)$ & $(1,1,3)$ & $(1,3,5)$ \\
20. & Candi Prambanan & $(3,5,5)$ & $(1,1,3)$ & \\
21. & Indrayanti & $(1,3,5)$ & $(1,1,3)$ & \\
22. & Rafting Sungai Elo & $(3,5,5)$ & & \\
23 & Keraton Jogja & $(1,3,5)$ & &
\end{tabular}


Table 3. Preference value of fuzzy SAW

\begin{tabular}{ccc}
\hline No. & Package Name & 0,6372 \\
\hline 1. & Gua Pindul1 & 0,7708 \\
2. & Kalibiru1 & 0,6372 \\
3. & Merapi Lava Tour & 0,5957 \\
4. & Rafting Sungai Elo & 0,6879 \\
5. & Snorkeling & 0,6879 \\
6. & Sunrise & 0,5543 \\
7. & Mangunan & 0,5543 \\
8. & Gua Pindul2 & 0,6372 \\
9. & Merapi & 0,5543 \\
10. & Kalibiru2 & 0,6372 \\
11. & Indrayanti & 0,605 \\
12. & Candi Borobudur & 0,4714 \\
13. & Gua Pindul3 & 0,6879 \\
14. & Hutan Pinus & 0,4714 \\
15. & Kalibiru3 & 0,8123 \\
16. & Air Terjun Sri Gethuk & 0,5543 \\
17. & Umbul Ponggok & 0,6879 \\
18. & Candi Prambanan & 0,605 \\
19. & Indrayanti & 0,5957 \\
20. & Rafting Sungai Elo & 0,605 \\
21. & Keraton Jogja & 0,4714 \\
22. & Dieng Wonosobo & 0,605 \\
23 & Keraton Solo & \\
\hline
\end{tabular}

From Table 3, it can be seen that the package with the highest preference value shows the best package for tourists to choose from. The Sri Gethuk Waterfall Package has the highest value because, with a cheap package price, it gets quite a lot of facilities and the largest number of participants, namely 5. Furthermore, several packages have low preference values, namely the Kalibiru3 Package, the Pindul3 Cave Package, and the Dieng Wonosobo Package. The three packages have relatively expensive prices for the number of participants as many as 3 people and fewer facilities too.

\section{CONCLUSION}

The Fuzzy SAW method can help tourists choose the best Tour and Travel package based on the three available criteria. From the SAW calculation, it can be seen that packages that have a preference value above 0.7 are highly recommended to be selected. Meanwhile, preference values above 0.6 to 0.7 are still considered to be selected, because they have an advantage in one of the criteria. For preference values below 0.6 it is not recommended to choose because the package is too expensive and not worth what you get.

\section{REFERENCES}

[1] O. I. Nima Farokhi, Mozhdeh Vahid, Mehrbakhsh Nilashi, “A multi-criteria recommender system for tourism using fuzzy approach,” J. Soft Comput. Decis. Support Syst., vol. 3, no. 4, pp. 19-29, 2016.

[2] M. O. Ilban and H. H. Y1ldırım, "Determination of tourism activities of the world's best tourism destinations using the multi-criteria decision-making method," Cogent Soc. Sci., vol. 3, no. 1, 2017 , doi: 10.1080/23311886.2017.1301763.

[3] H. Alrasheed, A. Alzeer, A. Alhowimel, N. Shameri, and A. Althyabi, "A multi-level tourism destination recommender system," Procedia Comput. Sci., vol. 170, pp. 333-340, 2020, doi: 10.1016/j.procs.2020.03.047.

[4] R. Schegg and B. Stangl, "Special section on recommendations and analytics in tourism," Inf. Technol. Tour., vol. 18, no. 1-4, 2018, doi: 10.1007/s40558-018-0109-8.

[5] M. A. Maulana, M. Habib, A. Setyanto, and Oktavia, "Tourism Trend Mapping Based on Social Media Using SAW Algorithm," J. Phys. Conf. Ser., vol. 1140, no. 1, 2018, doi: 10.1088/17426596/1140/1/012041.

[6] P. I. Ciptayani, N. G. A. P. H. Saptarini, P. A. W. Santiary, and I. N. G. A. Astawa, "Decision support system for tourist destination using the combination of ahp and saw," Proc. - 2nd East Indones. Conf. Comput. Inf. Technol. Internet Things Ind. EIConCIT 2018, pp. 271-275, 2018, doi: 10.1109/EIConCIT.2018.8878638.

[7] E. Charou, K. Kabassi, A. Martinis, and M. Stefouli, "Integrating multimedia GIS technologies in a recommendation system for geotourism," Smart Innov. Syst. Technol., vol. 3, pp. 63-74, 2010, doi: 10.1007/978-3-642-13396-1_3.

[8] K. Piasecki, E. Roszkowska, and A. Łyczkowska-Hanćkowiak, "Simple additive weighting method equipped with fuzzy ranking of evaluated alternatives," Symmetry (Basel)., vol. 11, no. 4, 2019, doi: 10.3390/sym11040482. 
[9] S. A. Pratiwi and H. Medyawati, "Design of supporting application for deciding the best mountain climbing 'Hiking-Yuk!,"' Int. J. Eng. Technol. Manag. Res., vol. 7, no. 2, pp. 53-80, 2020, doi: 10.29121/ijetmr.v7.i2.2020.510.

[10] M. Z. Rohman, Irwansyah, and W. E. Sari, "The medical facilities selection based on location-based services application using SAW and TOPSIS Algorithm,” J. Phys. Conf. Ser., vol. 1577, no. 1, 2020, doi: 10.1088/1742-6596/1577/1/012012.

[11] H. A. Prihanditya, "The implementation of z-score normalization and boosting techniques to increase accuracy of c4.5 algorithm in diagnosing chronic kidney disease," J. Soft Comput. Explor., vol. 5, no. 1, pp. 63-69, 2020.

[12] A. Cahyapratama and R. Sarno, "Application of Analytic Hierarchy Process (AHP) and Simple Additive Weighting (SAW) methods in singer selection process," 2018 Int. Conf. Inf. Commun. Technol. ICOIACT 2018, vol. 2018-Janua, pp. 234-239, 2018, doi: 10.1109/ICOIACT.2018.8350707.

[13] M. Saputra, O. S. Sitompul, and P. Sihombing, "Comparison AHP and SAW to promotion of head major department SMK Muhammadiyah 04 Medan,” J. Phys. Conf. Ser., vol. 1007, no. 1, 2018, doi: 10.1088/1742-6596/1007/1/012034.

[14] M. M. D. Widianta, T. Rizaldi, D. P. S. Setyohadi, and H. Y. Riskiawan, "Comparison of multi-criteria decision support methods (AHP, TOPSIS, SAW \& PROMENTHEE) for employee placement," $J$. Phys. Conf. Ser., vol. 953, no. 1, 2018, doi: 10.1088/1742-6596/953/1/012116.

[15] I. Tahyudin, R. Rosyidi, A. S. Ahmar, and Haviluddin, "Comparison of the simple additive weighting (SAW) with the technique for others reference by similarity to ideal solution (TOPSIS) methods," Int. J. Eng. Technol., vol. 7, no. 2, pp. 87-89, 2018, doi: 10.14419/ijet.v7i2.2.12740.

[16] R. Simanaviciene and L. Ustinovichius, "Sensitivity analysis for multiple criteria decision-making methods: TOPSIS and SAW," Procedia - Soc. Behav. Sci., vol. 2, no. 6, pp. 7743-7744, 2010, doi: 10.1016/j.sbspro.2010.05.207.

[17] A. M. Yaakob and A. Gegov, "Interactive TOPSIS Based Group Decision Making Methodology Using Z-Numbers," Int. J. Comput. Intell. Syst., vol. 9, no. 2, pp. 311-324, 2016, doi: 10.1080/18756891.2016.1150003.

[18] D. J, Windarsyah, and R. R, "Decision support system for selecting banjar restaurant in banjarmasin city using simple additive weighting method," J. K6, Educ. Manag., vol. 1, no. 4, pp. 35-43, 2018, doi: 10.11594/jk6em.01.04.05.

[19] A. Göksu and Seniye Erdinç Kaya, "Ranking of tourist destinations with multi-criteria decision making methods in bosnia and herzegovina," Econ. Rev. J. Econ. Bus., vol. 12, no. 2, pp. 91-103, 2014.

[20] J. Seyedmohammadi, F. Sarmadian, A. A. Jafarzadeh, M. A. Ghorbani, and F. Shahbazi, "Application of SAW, TOPSIS and fuzzy TOPSIS models in cultivation priority planning for maize, rapeseed and soybean crops," Geoderma, vol. 310, pp. 178-190, 2018, doi: 10.1016/j.geoderma.2017.09.012.

[21] D. Aprilianto, "SVM Optimization with correlation feature selection based binary particle swarm optimization for diagnosis of chronic kidney disease," J. Soft Comput. Explor., vol. 1, no.1 pp. 24-31, 2020.

[22] A. R. Safitri and M. A. Muslim, "Improved accuracy of naive bayes classifier for determination of customer churn uses smote and genetic algorithms," J. Soft Comput. Explor., vol. 1, no. 1, pp. 70-75, 2020.

[23] R. H. Saputra and B. Prasetyo, "Improve the accuracy of c.5 algorithm using Particle Swarm Optimization (PSO) feature selection and bagging technique in breast cancer diagnosis," J. Soft Comput. Explor., vol. 1. no.1. pp. 47-55, 2020. 